\title{
Inhibitory effect of fermented Arctium lappa fruit extract on the IgE-mediated allergic response in RBL-2H3 cells
}

\author{
JAE-MYUNG YOO, JU HYE YANG, HYE JIN YANG, WON-KYUNG CHO and JIN YEUL MA
}

Korean Medicine (KM)-Application Center, Korea Institute of Oriental Medicine (KIOM), Daegu 41062, Republic of Korea

Received September 3, 2015; Accepted December 15, 2015

DOI: $10.3892 / \mathrm{ijmm} .2015 .2447$

\begin{abstract}
Arctium lappa fruit has been used in traditional medicine, and it is known to exert beneficial effects, such as antioxidant, anti-inflammatory and anticancer effects. However, the effects of the Arctium lappa fruit on the allergic response remain unknown. In this study, we evaluated the anti-allergic effects of Arctium lappa fruit extract (AFE) and its fermented form (F-AFE) using immunoglobulin E (IgE)-activated RBL-2H3 cells. To investigate the anti-allergic effects of AFE or F-AFE, we examined the release of $\beta$-hexosaminidase, a key biomarker of degranulation during an allergic reaction, and the production of pro-inflammatory mediators, such as tumor necrosis factor- $\alpha$ (TNF- $\alpha$ ) and prostaglandin $\mathrm{E}_{2}\left(\mathrm{PGE}_{2}\right)$ in the cells treated with or without the above-mentioned extracts. AFE weakly inhibited the release of $\beta$-hexosaminidase, whereas F-AFE significantly suppressed the release of $\beta$-hexosaminidase in a dose-dependent manner. Consistently, F-AFE suppressed the production of TNF- $\alpha$ and $\mathrm{PGE}_{2}$ in a dose-dependent manner. F-AFE exerted an inhibitory effect on the production of $\beta$-hexosaminidase, TNF- $\alpha$ and $\mathrm{PGE}_{2}$ with an $\mathrm{IC}_{50}$ value of $30.73,46.96$ and $36.27 \mu \mathrm{g} / \mathrm{ml}$, respectively. Furthermore, F-AFE inhibited the phosphorylation of Lyn, Fyn and Syk, which are involved in the FceRI signaling pathway, that of phosphoinositide phospholipase C (PLC) $\gamma 1 / 2$ and protein kinase $\mathrm{C}(\mathrm{PKC}) \delta$, which are associated with the degranulation process, as well as that of extracellular signal-regulated kinase 1/2 (ERK1/2), c-Jun $N$-terminal kinase 1/2 (JNK), p38 and Akt, which are associated with cytokine expression. In the late phase, F-AFE partially suppressed the phosphorylation of cytosolic phospholipase $\mathrm{A}_{2}\left(\mathrm{cPLA}_{2}\right)$, but not the expression of cyclooxygenase (COX)-2. To compare and identify the major components of the two extracts, we used high-performance liquid chromatography. The levels of arctigenin, one of the major compounds, were elevated 6-fold in F-AFE compared with
\end{abstract}

Correspondence to: Dr Won-Kyung Cho or Dr Jin Yeul Ma, Korean Medicine (KM)-Application Center, Korea Institute of Oriental Medicine (KIOM), 70 Cheomdan-ro, Dong-gu, Daegu 41062, Republic of Korea

E-mail:wkcho@kiom.re.kr

E-mail: jyma@kiom.re.kr

Key words: Arctium lappa fruit, fermentation, degranulation, FceRI, Syk, tumor necrosis factor- $\alpha$, prostaglandin $\mathrm{E}_{2}$
AFE, whereas the levels of arctiin, an arctigenin glycoside, were decreased in F-AFE by approximately $57.40 \%$. These results suggest that arctigenin plays an important role in the anti-allergic effects of F-AFE. Taken together, F-AFE containing anti-allergic phytochemicals, including arctigenin, inhibited the activation of the FceRI receptor induced by the antigen-IgE complex. Such effects may provide further information for the development of a phytomedicine for allergic diseases.

\section{Introduction}

Arctium fruit (Arctium lappa L.) has been used in traditional herbal medicine in East Asia, and is known to exert various beneficial, such as antioxidant (1), anticancer (2), anti-aging (3), anti-diabetes (4), neuroprotective (5), hepatoprotective (6) and anti-colitis (7) effects. Such effects are associated with polyphenol compounds, such as arctigenin, arctiin and other lignan compounds in Arctium lappa fruit $(1,2,4,6,8)$. However, to the best of our knowledge, the effects of Arctium lappa fruit or its fermentation product on allergic reactions have not been reported to date.

The fermentation process for medicinal herbs has been frequently used for improving the biological effects of the extracts $(9,10)$. Fermentation using microorganisms, such as yeast (11), fungi $(12)$ and bacteria $(9,10)$ is known to yield metabolites, or to convert glycosylated compounds into aglycones, one of the active forms.

Anaphylactic shock is known as the type I of allergic response classes (13), and is the most important clinically, as anaphylactic shock is closely associated with the degranulation of mast cells (14). When mast cells are activated by the antigen-immunoglobulin E ( IgE) complex, they are then able to release a number of allergic inflammatory mediators, such as histamine, cytokines, prostaglandins and leukotrienes from numerous granules in a matter of minutes (15). Consequently, tissues or organs stimulated by allergic inflammatory mediators induce acute inflammatory responses simultaneously. In signaling cascades associated with allergic reactions, the FceRI receptor is known as the high affinity $\operatorname{IgE}$ receptor, and is located on the plasma membrane of mast cells and basophilic cells (15). Therefore, the activation of the receptor on mast cells is intimately associated with degranulation or biosynthesis of the allergic inflammatory mediators in mast cells.

In present study, we found that Arctium lappa fruit extract (AFE) exerted mild anti-allergic effects. Based on this 
finding, we hypothesized that the fermentation process may improve the anti-allergic effects of AFE on IgE-activated mast cells. To investigate anti-allergic effects of fermented AFE (F-AFE), degranulation was determined by measuring $\beta$-hexosaminidase activity in IgE-activated RBL-2H3 cells. To examine the anti-allergic and anti-inflammatory effects of F-AFE, the levels of inflammatory biomarkers, including tumor necrosis factor- $\alpha(\mathrm{TNF}-\alpha)$ and prostaglandin $\mathrm{E}_{2}\left(\mathrm{PGE}_{2}\right)$ were measured. Finally, to elucidate the mechanisms and active compounds responsible for the anti-allergic effects of F-AFE, the FceRI signaling cascade was analyzed by immumoblotting analysis, and the active phytochemical composition of F-AFE was analyzed by high-performance liquid chromatography (HPLC). Herein, we demonstrate that F-AFE suppresses IgE-mediated allergic events in mast cells. Furthermore, our data may aid in the development of a phytomedicine for allergic diseases.

\section{Materials and methods}

Reagents. MEM- $\alpha$ medium, $1 \mathrm{X}$ Dulbecco's phosphatebuffered saline (DPBS), penicillin, streptomycin and fetal bovine serum (FBS) were purchased from GE Healthcare Life Sciences (HyClone, Logan, UT, USA). The EZ-Cytox cell viability assay kit was purchased from DAEIL Lab Service Co. Ltd. (Seoul, Korea). Specific antibodies against phosphorylated (p-)Lyn (\#2731), p-Syk (\#2710), p-phosphoinositide phospholipase C (PLC) $\gamma 1 / 2$ (\#2821, \#3871, respectively), p-protein kinase C (PKC) $\delta$ (\#2055), p-extracellular signal-regulated kinase 1/2 (ERK1/2; \#9101), p-c-Jun $N$-terminal kinase 1/2 (p-JNK; \#9251), p-p38 (\#9211), p-Akt (\#9271), p-cytosolic phospholipase $\mathrm{A}_{2}$ (cPLA \#2831) and cyclooxygenase (COX)-2 (\#4842) were obtained from Cell Signaling Technology (Beverly, MA, USA). A specific antibody against p-Fyn (orb128087) was purchased from Biorbyt Ltd. (Cambridge, UK). A specific antibody against $\beta$-actin (sc-47778) was obtained from Santa Cruz Biotechnology, Inc. (Dallas, TX, USA). The enzyme immunoassay (EIA) kit for $\mathrm{PGE}_{2}$ was obtained from Cayman Chemical Co. (Ann Arbor, MI, USA). The enzyme-linked immunosorbent assay (ELISA) kit for TNF- $\alpha$ was purchased from e-Bioscience, Inc. (Science Center Drive, San Diego, CA, USA). 4-Nitrophenyl $N$-acetyl- $\beta$ - $D$-glucosaminide (p-NAG), dinitrophenyl (DNP)-immunoglobulin E (DNP-IgE) and DNP-human serum albumin (DNP-HSA) were obtained from Sigma-Aldrich (St. Louis, MO, USA). The standards of arctiin and matairesinol were purchased from Wuhan ChemFaces Biochemical Co., Ltd. (Wuhan, China). A standard of arctigenin was obtained from Must Bio-Technology Co., Ltd. (Chengdu, China). All other chemicals were of analytical grade.

Preparation of extracts of Arctium lappa fruit or fermented Arctium lappa fruit. AFE or F-AFE were prepared according to a modification of a process reported previously (16); Arctium lappa fruits were purchased from the Yeongcheon Oriental Herbal Market (Yeongcheon, Korea), and were then verified by Dr Ki-Hwan Bae, who holds the position of Professor Emeritus at the College of Pharmacy, Chungnam National University (Daejeon, Korea). Arctium lappa fruits (1 kg) were boiled in distilled water (10 liter) for approximately $3 \mathrm{~h}$ at $115^{\circ} \mathrm{C}$. The aqueous extract was filtered through a testing sieve (aperture 500 and $150 \mu \mathrm{m})$. AFE was fermented using Lactobacillus rhamnosus (L. rhamnosus) (KFRI 128, KCTC 2182) provided from the Korea Food Research Institute. Briefly, the water extract adjusted to $\mathrm{pH} 7.0$ with $1 \mathrm{~N} \mathrm{NaOH}$ was autoclaved for $5 \mathrm{~min}$, inoculated with L. rhamnosus $\left(1 \times 10^{5}-1 \times 10^{7} \mathrm{CFU} / \mathrm{ml}\right)$, and then incubated for $48 \mathrm{~h}$ at $37^{\circ} \mathrm{C}$ for $48 \mathrm{~h}$. F-AFE was filtered through a $60-\mu \mathrm{m}$ nylon net filter (Millipore, Billerica, MA, USA), deposited overnight. The supernatant was lyophilized, and the dried pellet was then stored at $-20^{\circ} \mathrm{C}$ until use. AFE and F-AFE were dissolved in $10 \%$ DMSO solution for use in all the experiments.

HPLC analysis. HPLC analysis was evaluated following a modification of a previously described method (17). To analyze the lignan compounds, HPLC analysis was performed using a Chromeleon 7 system equipped with a Dionex UltiMate 3000 Pump, an autosampler, a column compartment and a diode array detector (Thermo Fisher Scientific Inc., Foster City, CA, USA) and a Phenomenex Luca $\mathrm{C}_{18}$ column $(4.6 \times 250 \mathrm{~mm}$, $5 \mu \mathrm{m}$; Phenomenex Inc., Torrance, CA, USA). The lignan chemicals were eluted in a gradient system composed of solvent A (deionized water) and solvent B (acetonitrile). The gradient was 20-30-36-45-90-20\% of solvent B at gradient time, $t \mathrm{G}=0-20-35-50-53-75 \mathrm{~min}$, column oven temperature was $30^{\circ} \mathrm{C}$ and the flow rate was $1.0 \mathrm{ml} / \mathrm{min}$; an injection volume of $10 \mu \mathrm{l}$ was applied. The UV/Vis detector was set at a wavelength range from 190 to $400 \mathrm{~nm}$. The standards of arctiin, arctigenin or matairesinol and sample solutions $(1.0 \mathrm{mg} / \mathrm{ml})$ were dissolved and diluted in $60 \%$ methanol. Calibration curves constructed using linear least-squares regression were linear over the concentration range of the standards used (Table I). The relative standard deviation of the measured concentrations was used to assess the precision. A comparison of the mean measured concentration versus the corresponding nominal concentration was used to assess the accuracy.

Cell culture. RBL-2H3 cells, originating from rat basophilic leukemia and known as one of the mast cell lines, were obtained from the Korean Cell Line Bank (Seoul, Korea), and were cultured in MEM- $\alpha$ medium containing $10 \%$ (v/v) FBS, $100 \mathrm{U} / \mathrm{ml}$ penicillin and $100 \mu \mathrm{g} / \mathrm{ml}$ streptomycin at $37^{\circ} \mathrm{C}$ in a humidified atmosphere of $5 \% \mathrm{CO}_{2}$ as previously described (18). All the experiments included a control group, which was a vehicle control group (0.1\% DMSO).

Cell viability assay. Cell viability was determined by measuring the mitochondrial-dependent reduction of WST-1 to watersoluble tetrazolium salt (19). Briefly, the RBL-2H3 cells were seeded on a $96-$-well plate $\left(1 \times 10^{4}\right.$ cells/well $)$ in MEM- $\alpha$ medium with $10 \% \mathrm{FBS}$ at $37^{\circ} \mathrm{C}$ overnight. The cells were washed by 1X DPBS, and then incubated with $50 \mathrm{ng} / \mathrm{ml}$ DNP-IgE for $24 \mathrm{~h}$. The above-mentioned cells, pre-incubated with AFE $(0-2,500 \mu \mathrm{g} /$ $\mathrm{ml})$ or F-AFE $(0-500 \mu \mathrm{g} / \mathrm{ml})$ for $1 \mathrm{~h}$ in Hank's balanced salt solution (HBSS) containing $0.1 \%$ BSA, were simultaneously mixed with $0.1 \mu \mathrm{g} / \mathrm{ml}$ DNP-HSA and $10 \mu \mathrm{l}$ EZ-Cytox reagent, and then incubated for a further $4 \mathrm{~h}$. Cell viability was determined at $450 \mathrm{~nm}$ using a microplate reader (SpectraMax i3; Molecular Devices, Sunnyvale, CA, USA).

$\beta$-hexosaminidase activity assay. $\beta$-hexosaminidase activity was evaluated according to a previously described method (20). The 
Table I. Calibration curves of three lignan standards.

\begin{tabular}{lccc}
\hline Lignan compound & Regression equation & Correlation coefficient $\left(\mathrm{r}^{2}\right)^{\mathrm{b}}$ & Linear range $(\mu \mathrm{g})$ \\
\hline Arctiin & $\mathrm{y}=0.0916 \mathrm{x}+0.0737$ & 10.000 & $37.5-600.0$ \\
Arctigenin & $\mathrm{y}=63597 \mathrm{x}-2277.6$ & 10.000 & $12.5-200.0$ \\
Methylarctigenin & $\mathrm{y}=119193 \mathrm{x}-18355$ & 10.000 & $5.0-80.0$ \\
\hline
\end{tabular}

${ }^{\mathrm{a}} \mathrm{y}$, peak area; $\mathrm{x}$, concentration $(\mu \mathrm{g} / \mathrm{ml})$; ${ }^{\mathrm{b}}$ regression coefficient $(\mathrm{n}=5)$.

supernatant $(25 \mu \mathrm{l})$ was mixed with $50 \mu \mathrm{l}$-NAG $(10 \mathrm{mM})$ in $0.1 \mathrm{M}$ sodium citrate buffer $(\mathrm{pH} 4.5)$ in a 96-well plate, followed by incubation for $1 \mathrm{~h}$ at $37^{\circ} \mathrm{C}$. The reaction was terminated by stop buffer (0.1 M sodium carbonate buffer, $\mathrm{pH} 10.0$ ). The absorbance was measured at $405 \mathrm{~nm}$ using a microplate reader.

ELISA for determining the levels of TNF- $\alpha$. To determine the levels of TNF- $\alpha$ in the culture media, the IgE-sensitized cells were pre-incubated with F-AFE $(0-500 \mu \mathrm{g} / \mathrm{ml})$ for $1 \mathrm{~h}$ in MEM- $\alpha$ medium with $0.1 \%$ FBS for $1 \mathrm{~h}$, spiked with DNP-HSA, and then incubated for a further $4 \mathrm{~h}$. All culture media were centrifuged $(17,000 \mathrm{x}$ g for $10 \mathrm{~min})$ at $4^{\circ} \mathrm{C}$, and the samples were stored at $-80^{\circ} \mathrm{C}$ until use. TNF- $\alpha$ was detected using an ELISA kit according to the manufacturer's instructions (e-Bioscience, Inc.).

EIA for determining the levels of $P G E_{2}$. To measure the levels of $\mathrm{PGE}_{2}$ in the culture media, all culture media were centrifuged $(17,000 \mathrm{x} \mathrm{g}$ for $10 \mathrm{~min})$ at $4^{\circ} \mathrm{C}$, and the samples were stored at $-80^{\circ} \mathrm{C}$ until use. $\mathrm{PGE}_{2}$ was measured using an EIA kit according to the manufacturer's instructions (Cayman Chemical Co.).

Immunoblot analysis. Immunoblot analysis was carried out according to a previously described method (20). PVDF membranes containing blotted proteins were visualized using a chemiluminescent reaction (ECL plus kit) and an Imaging system (ChemiDoc Touch Imaging System) (both from Bio-Rad, Hercules, CA, USA). The levels of target proteins were compared to those of a loading control ( $\beta$-actin), and the results were expressed as a ratio of the density of each protein identified by a protein standard size marker (BIOFACT Co., Ltd., Daejeon, Korea). The density of each band was measured using ImageJ software (version $1.49 \mathrm{v}$ for Windows; NIH, Bethesda, MD, USA).

Statistical analyses. The experimental results are presented as the means $\pm \mathrm{SD}$. One-way analysis of variance (ANOVA) was used for multiple comparisons (GraphPad Prism version 5.01 for Windows; GraphPad Software, San Diego, CA, USA). If there was a significant variation between the treatment groups, the Dunnett's test was applied. Values of $\mathrm{P}<0.05$ and $\mathrm{P}<0.01$ were considered to indicate statistically significant differences.

\section{Results}

Inhibitory effects of AFE or F-AFE on IgE-mediated degranulation in RBL-2H3 cells: comparison between AFE and F-AFE. First, to investigate effects of AFE and F-AFE on IgE-mediated degranulation in mast cells, the IgE-sensitized RBL-2H3 cells
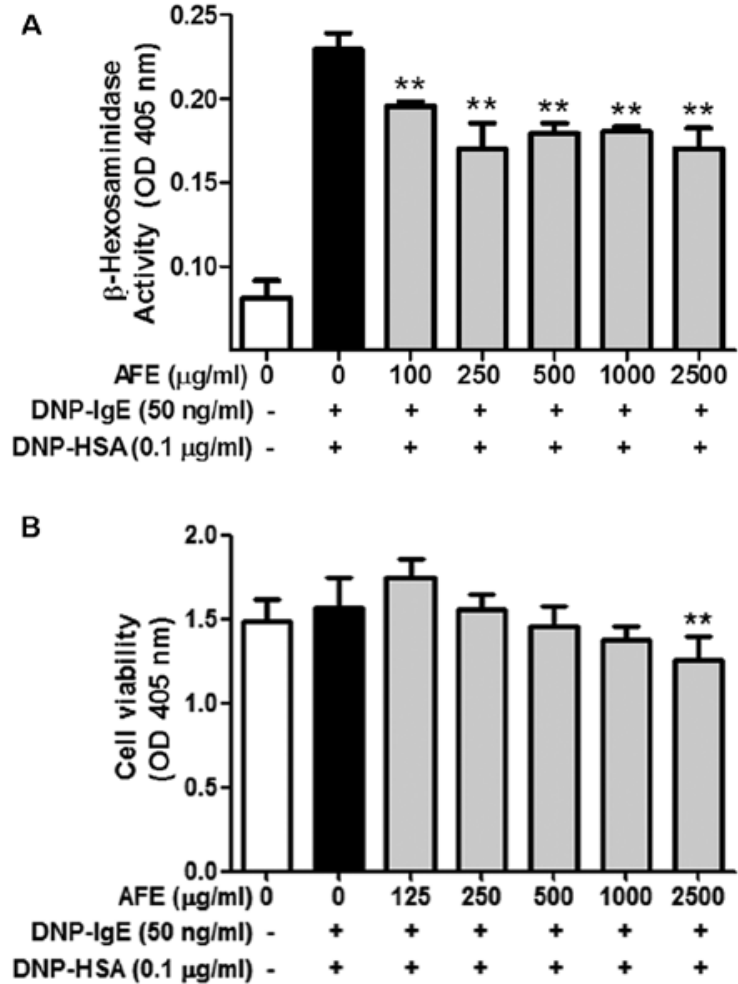

Figure 1. Effects of Arctium lappa fruit extract (AFE) on degranulation and cell viability in immunoglobulin E (IgE)-activated RBL-2H3 cells. RBL-2H3 cells were seeded on a 24 -well plate $\left(1 \times 10^{5}\right.$ cells/well) or a 96 -well plate $\left(1 \times 10^{4}\right.$ cells/well) in MEM- $\alpha$ with $10 \%$ FBS at $37^{\circ} \mathrm{C}$ overnight, and further incubated with dinitrophenyl (DNP)-IgE for $24 \mathrm{~h}$. IgE-sensitized cells were exposed to AFE $(0-2,500 \mu \mathrm{g} / \mathrm{ml})$ for $1 \mathrm{~h}$, and then stimulated with DNP-HSA $(0.1 \mu \mathrm{g} / \mathrm{ml})$ for $4 \mathrm{~h}$. $\beta$-hexosaminidase activity and cell viability were determined as described in the Materials and methods. Data are the mean \pm SD values of triple or octuplex determinations. ${ }^{* *} \mathrm{P}<0.01$ vs. DNP-HSA-treated group. (A) $\beta$-hexosaminidase; (B) cell viability.

were incubated with various concentrations of AFE or F-AFE prior to exposure to the antigen $(0.1 \mu \mathrm{g} / \mathrm{ml}$ DNP-HSA). Although AFE weakly inhibited the release of $\beta$-hexosaminidase, a marker of degranulation, from the IgE-activated RBL-2H3 cells until $2,500 \mu \mathrm{g} / \mathrm{ml}$, the inhibitory effect of AFE was not enhanced after $250 \mu \mathrm{g} / \mathrm{ml}$ (Fig. 1A). On the other hand, F-AFE markedly inhibited degranulation ( $\mathrm{IC}_{50}$ value, $30.73 \mu \mathrm{g} / \mathrm{ml}$ ) in the IgE-activated RBL-2H3 cells in a dose-dependent manner (Fig. 2A). Notably, neither AFE nor F-AFE exerted any severe cytotoxic effects at concentrations of up to $1,000 \mu \mathrm{g} / \mathrm{ml}$ and $250 \mu \mathrm{g} / \mathrm{ml}$, respectively (Figs. $1 \mathrm{~B}$ and $2 \mathrm{~B}$ ). These results indicate that fermentation of the Arctium lappa fruit potently enhances the anti-allergic effects of AFE within non-cytotoxic concentrations. 
A

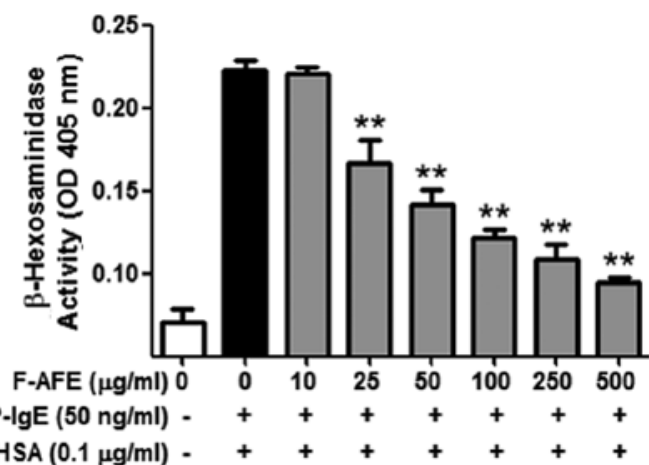

B

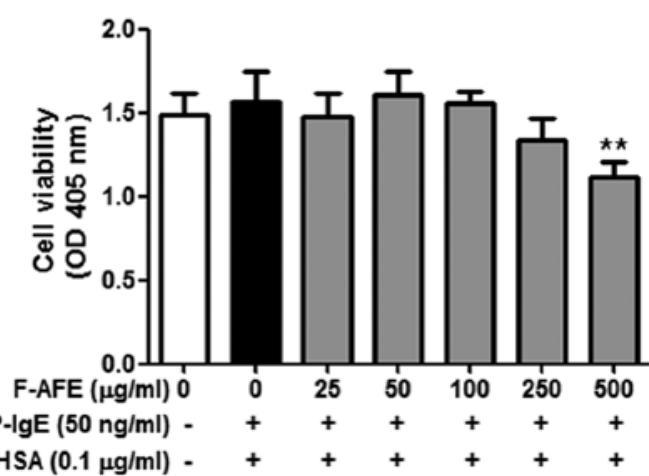

Figure 2. Effect of fermented Arctium lappa fruit extract (F-AFE) on degranulation and cell viability in immunoglobulin E (IgE)-activated RBL-2H3 cells $\beta$-hexosaminidase activity and cell viability were determined as described in Fig. 1. Data are the mean \pm SD values of triple or octuplex determinations. ${ }^{* *} \mathrm{P}<0.01$ vs. DNP-HSA-treated group. (A) $\beta$-hexosaminidase; (B) cell viability.

Inhibitory effects of $F$-AFE on the release of pro-inflammatory mediators. It is known that IgE-activated mast cells are able to release pro-inflammatory mediators, such as TNF- $\alpha$, associated with the initiation of airway inflammation and the generation of airway hyper-responsiveness in asthma (21), and $\mathrm{PGE}_{2}$, associated with asthma development and inflammation (22). Therefore, we focused on the effects of F-AFE on the release of TNF- $\alpha$ and $\mathrm{PGE}_{2}$ from IgE-activated RBL-2H3 cells. When the IgE-sensitized RBL-2H3 cells were pre-incubated with F-AFE and stimulated with the antigen, F-AFE significantly decreased the release of TNF- $\alpha$ with an $\mathrm{IC}_{50}$ value of $46.96 \mu \mathrm{g} / \mathrm{ml}$ (Fig. 3A) and that of $\mathrm{PGE}_{2}$ with an $\mathrm{IC}_{50}$ value of $36.27 \mu \mathrm{g} / \mathrm{ml}$ (Fig. 3B). These results suggest that F-AFE suppresses acute or chronic allergic inflammatory responses by inhibiting the release of various inflammatory mediators, including cytokines and lipid mediators from IgE-activated mast cells.

Regulatory effects of F-AFE on the activation of the arachidonate cascade. We wished to examine the effects of F-AFE on the formation of pro-inflammatory lipid mediators, as pro-inflammatory lipid mediators, including $\mathrm{PGE}_{2}$, prostaglandin $\mathrm{D}_{2}\left(\mathrm{PGD}_{2}\right)$, leukotriene $\mathrm{B}_{4}\left(\mathrm{LTB}_{4}\right)$ and leukotriene $\left.\mathrm{C}_{4} \mathrm{LTC}_{4}\right)$ are known to aggravate allergic diseases (23-26). Thus, we investigated the effects of F-AFE on the phosphorylation of $\mathrm{cPLA}_{2}$, a rate-limiting enzyme of eicosanoid synthesis, and the expression of COX-2, a rate-limiting enzyme of prostaglandins. When the IgE-sensitized RBL-2H3 cells were incubated with F-AFE prior to antigen challenge for $4 \mathrm{~h}, \mathrm{~F}-\mathrm{AFE}$ partially suppressed the phosphorylation of $\mathrm{CPLA}_{2}$, but not the expression of COX-2 (Fig. 4). These findings
A

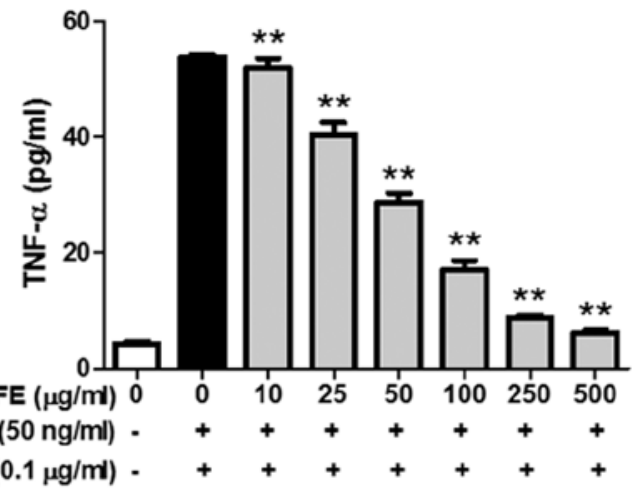

B

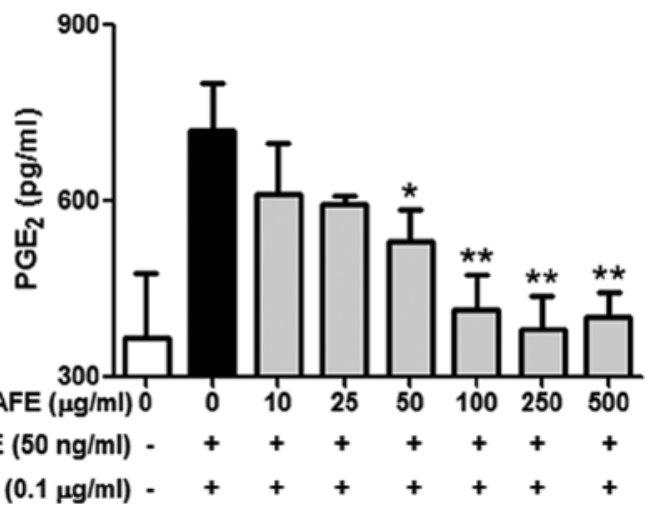

Figure 3. Inhibitory effects of fermented Arctium lappa fruit extract (F-AFE) on pro-inflammatory mediators. Immunoglobulin E (IgE)-sensitized RBL-2H3 cells were exposed to F-AFE $(0-500 \mu \mathrm{g} / \mathrm{ml})$ for $1 \mathrm{~h}$, and then stimulated with dinitrophenyl-human serum albumin (DNP-HSA) $(0.1 \mu \mathrm{g} / \mathrm{ml})$ for $4 \mathrm{~h}$. The levels of tumor necrosis factor- $\alpha$ (TNF- $\alpha)$ and prostaglandin $\mathrm{E}_{2}\left(\mathrm{PGE}_{2}\right)$ were determined as described in the Materials and methods. Data are the mean \pm SD values of triple determinations. ${ }^{*} \mathrm{P}<0.05$ and ${ }^{* *} \mathrm{P}<0.01$ vs. DNP-HSA-treated group. (A) TNF- $\alpha$; (B) $\mathrm{PGE}_{2}$.

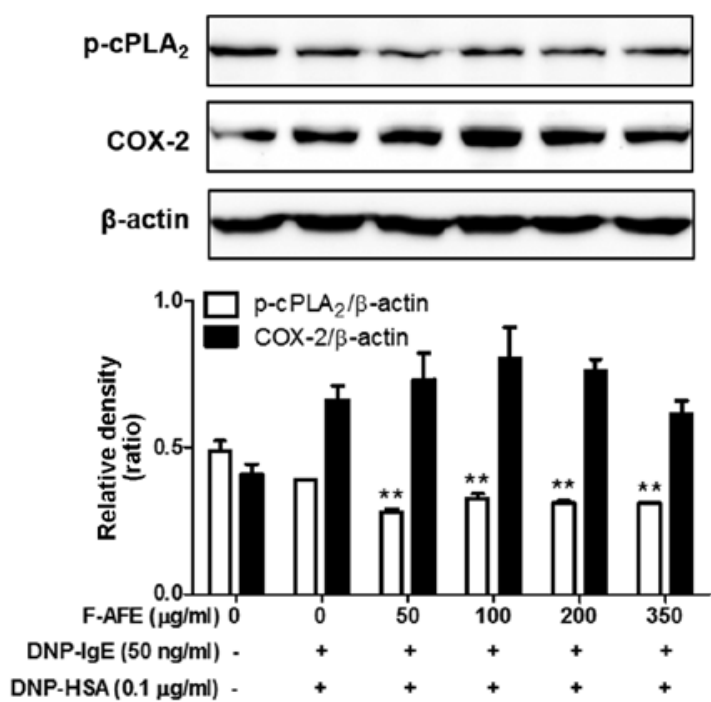

Figure 4. Inhibitory effects of fermented Arctium lappa fruit extract (F-AFE) on the activation of rate-limiting enzymes in the arachidonate cascade. RBL-2H3 cells were seeded on a 6 -well plate $\left(5 \times 10^{5}\right.$ cells/well) in MEM-a with $10 \% \mathrm{FBS}$ at $37^{\circ} \mathrm{C}$ overnight, and further incubated with dinitrophenylimmunoglobulin E (DNP-IgE) for $24 \mathrm{~h}$. IgE-sensitized RBL-2H3 cells were exposed to F-AFE $(0-350 \mu \mathrm{g} / \mathrm{ml})$ for $1 \mathrm{~h}$, and then stimulated with dinitrophenyl-human serum albumin (DNP-HSA) $(0.1 \mu \mathrm{g} / \mathrm{ml})$ for $4 \mathrm{~h}$. The above cells were rinsed with $1 \mathrm{X}$ DPBS, and lysed with cell lysis buffer. The expression of p-cPLA ${ }_{2}, \mathrm{COX}-2$ or $\beta$-actin was determined as described in the Materials and methods. Similar results were obtained from 3 independent experiments. ${ }^{* *} \mathrm{P}<0.01$ vs. DNP-HSA-treated group. 
A

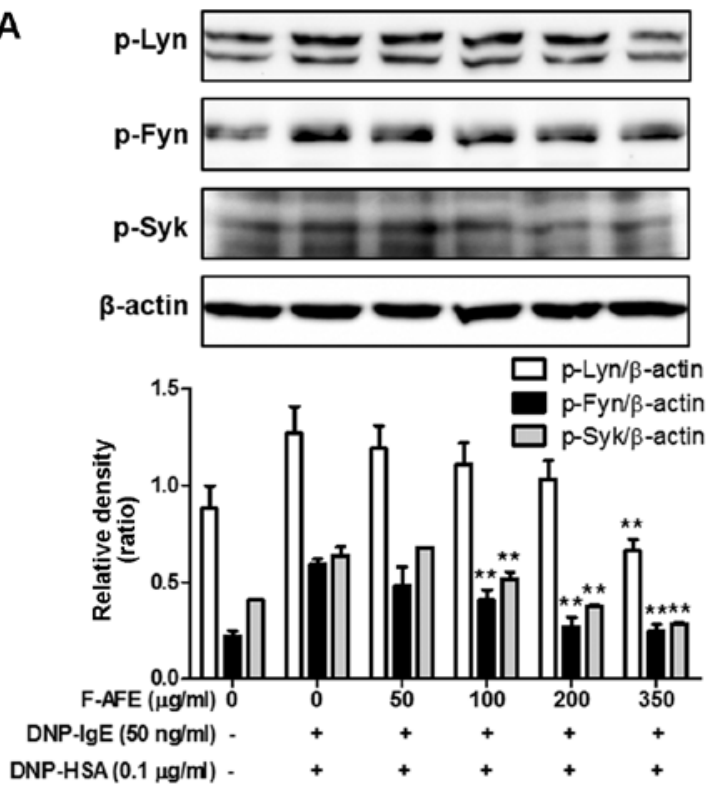

B
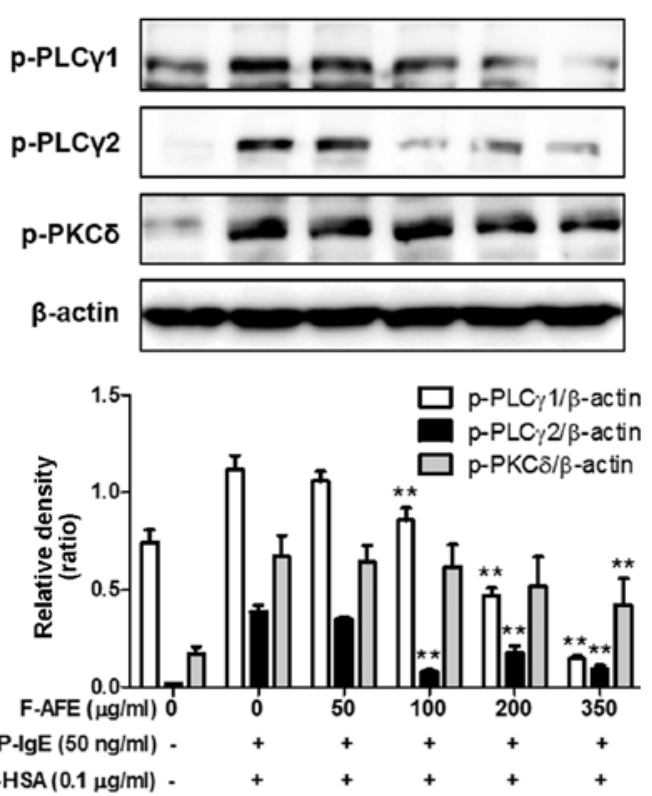
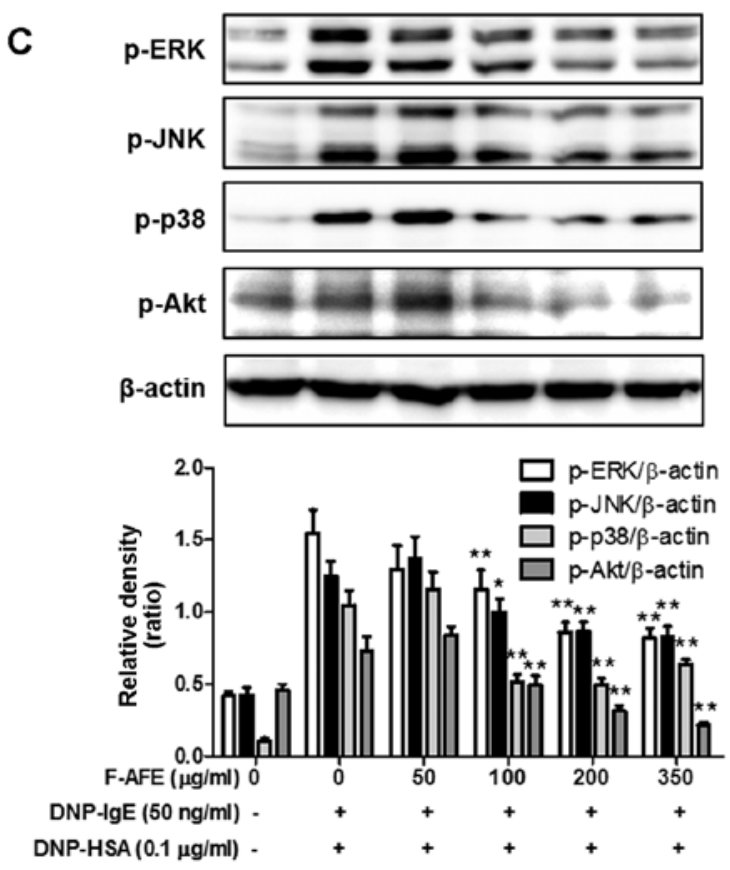

Figure 5. Effects of fermented Arctium lappa fruit extract (F-AFE) on the phosphorylation of intermediate proteins in the FceRI cascade. immunoglobulin E (IgE)-sensitized RBL-2H3 cells were exposed to F-AFE (0-350 $\mu \mathrm{g} / \mathrm{ml})$ for $1 \mathrm{~h}$, and then stimulated with dinitrophenyl-human serum albumin (DNP-HSA) $(0.1 \mu \mathrm{g} / \mathrm{ml})$ for $10 \mathrm{~min}$. The above-mentioned cells were rinsed with 1X DPBS, and lysed with cell lysis buffer. The expression of p-Lyn, p-Fyn, p-Syk, p-PLC $\gamma 1$, p-PLC $\gamma 2$, p-PKC $\delta$, p-ERK, p-JNK, p-p38, p-Akt, or $\beta$-actin was determined as described in the Materials and methods. Similar results were obtained from 3 independent experiments. "P $<0.05$ and ${ }^{* *} \mathrm{P}<0.01$ vs. DNP-HSA-treated group. (A) p-Lyn, p-Fyn and p-Syk; (B) p-PLC $\gamma 1, \mathrm{p}-\mathrm{PLC} \gamma 2$ and p-PKCס; (C) p-ERK, p-JNK, p-p38 and p-Akt.

indicate that F-AFE regulates the formation of eicosanoids, including prostaglandins by regulating the activation of $\mathrm{CPLA}_{2}$ in the arachidonate cascade.

Regulatory effects of F-AFE on the activation of the FcERI cascade. Since F-AFE reduced the rate-limiting enzymes of the arachidonate cascade in the late phase $(4 \mathrm{~h})$, we further investigated the rate-limiting proteins and intermediate proteins in the FceRI cascade in the early phase $(10 \mathrm{~min})$. The activation of the arachidonate cascade is involved in the IgE-mediated activation of the FceRI cascade in mast cells $(20,27)$. Thus, we wished to determine whether F-AFE regulates the activation of rate-limiting proteins and/or intermediate proteins in the IgE-mediated FceRI cascade. When the IgE-sensitized RBL-2H3 cells were stimulated with the antigen (DNP-HSA) for 10 min after the cells were incubated with F-AFE for $1 \mathrm{~h}$, F-AFE inhibited the phosphorylation of Lyn and Fyn, as well as that of Syk (Fig. 5A). In addition, F-AFE significantly reduced the phosphorylation of intermediate proteins, the downstream targets of Syk, such as ERK, JNK, p38 and Akt (Fig. 5C). Additionally, F-AFE significantly suppressed the phosphorylation of PLC $\gamma 1 / 2$ and $\mathrm{PKC} \delta$, which are involved 

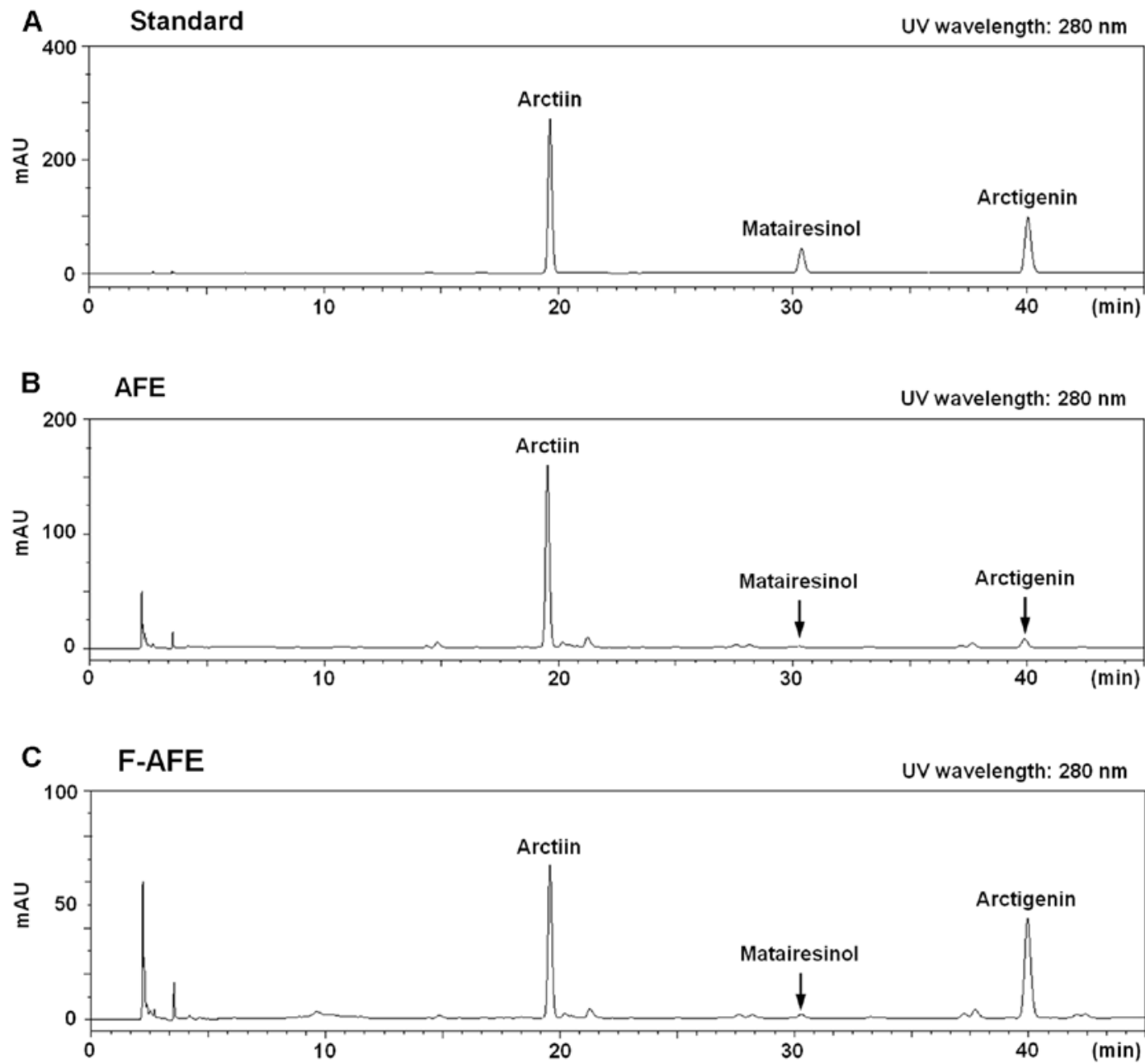

Figure 6. HPLC chromatograms of Arctium lappa fruit extract (AFE) or fermented AFE (F-AFE). These are HPLC chromatograms of a standard mixture of three standard chemicals in AFE or F-AFE at $280 \mathrm{~nm}$. Acrtiin (1), matairesinol (2) and acrtigenin (3) were identified. HPLC anlaysis was carried out as described in the Materials and methods. (A) Standard chromatogram; (B) AFE chromatogram; (C) F-AFE chromatogram.

Table II. Composition of AFE or F-AFE: lignan compounds.

\begin{tabular}{lccc}
\hline & \multicolumn{3}{c}{ Lignan compounds } \\
\cline { 2 - 4 } & Arctiin & Arctigenin & Methylarctigenin \\
\hline AFE & $338.79 \pm 0.01$ & $14.69 \pm 0.01$ & $1.80 \pm 0.37$ \\
F-AFE & $144.31 \pm 0.05$ & $88.35 \pm 0.07$ & $2.99 \pm 0.22$ \\
\hline
\end{tabular}

Data are the means \pm SD values of triple determinations. Unit: $\mathrm{mg} / \mathrm{g}$ dry weight.

in the degranulation process of mast cells (Fig. 5B). These findings indicate that the anti-allergic effects of F-AFE are associated with the regulation of the activation of the FceRI cascade through the inhibition of the activation of Lyn, Fyn and Syk in mast cells.

Identification of lignan compounds, one of the major components, in F-AFE: comparison between AFE and F-AFE. Finally, to substantiate what is behind the anti-allergic effects of F-AFE, we analyzed and compared the chemical composition of F-AFE and AFE using an HPLC system. It is known as that Arctium lappa fruit contains a number of lignan compounds, such as arctiin, arctigenin and other lignan compounds $(1,2,4,6,8)$. Based on the findings of these previous studies, we analyzed the amounts of the 3 major compounds: arctiin, matairesinol and arctigenin. The retention times for the peaks of the arctiin, matairesinol or arctigenin standard were $19.64,30.38$ or 40.06 min, respectively, as shown on an HPLC chromatogram (Fig. 6A). The peaks of matairesinol and arctigenin in F-AFE were increased, and the peak of arctiin in F-AFE was decreased on the HPLC chromatogram (Fig. 6B and C). Table II summarizes the amounts of arctiin, matairesinol and arctigenin in AFE and F-AFE. These results suggest that fermentation using L. rhamnosus elevates the levels of aglycones, such as arctigenin in AFE through conversion from lignan glycosides, such as arctiin. Taken together, our findings indicate that F-AFE has the potential for use as an antiallergic remedy, and that aglycones including arctigenin in AFE are responsible for the anti-allergic effects.

\section{Discussion}

Arctium lappa fruit has long been used in traditional herbal medicine in East Asia, and has been shown to exert various 
beneficial effects, such as antioxidant (1), anticancer (2), anti-aging (3), anti-diabetic (4), neuroprotective (5), hepatoprotective (6) and anti-colitis (7) effects. Such effects of the Arctium lappa fruit are caused by lignan compounds (1-7). However, to the best of our knowledge, the effects of the Arctium lappa fruit on allergic reaction have not been reported to date.

Various fermented foods have been consumed for centuries worldwide. In addition, several fermented foods have also been used in traditional medicine. Currently, the application of the fermentation process using microorganisms, such as fungi, yeast and bacteria has been often used to improve the beneficial effects of medicinal herbs (9-12). Fermentation is known for yielding metabolites, or converting glycosylated compounds to aglycones, one of the active forms. The fermentation process is known to yield metabolites of microorganisms, or convert glycosides to aglycones $(11,12,28)$. Nevertheless, the application of the fermentation process for the Arctium lappa fruit has been not reported to date, to the best of our knowledge.

Generally, Arctium lappa fruit is known to contain various lignan compounds, such as arctiin, arctigenin and methylarctigenin $(1,2,4,6,8,29)$. In particular, arctigenin is known as one of the major lignan compounds (29), and is a major effective component $(5,7,30)$ in the Arctium lappa fruit. These data demonstrate that AFE possesses weak anti-allergic properties. By contrast, as shown in this study, F-AFE, fermented using L. rhamnosus, exerted potent anti-allergic effects, as shown by cultured cell-based assays. F-AFE also contains elevated levels of aglycones, such as arctigenin, as shown by HPLC analysis. Therefore, F-AFE possesses an advantage in comparison with AFE, as F-AFE is much more potent than AFE in suppressing the biomarkers for degranulation ( $\beta$-hexosaminidase) and inflammation (TNF- $\alpha$ and $\mathrm{PGE}_{2}$ ) at several dozen microgram per milliliter levels. Actually, F-AFE contains 6-fold higher levels of arctigenin than AFE, whereas the acrtiin level was decreased in F-AFE by approximately $57.40 \%$ compared to AFE. This indicates that the anti-allergic effects of F-AFE may be caused by the elevated levels of arctigenin. Although F-AFE at $500 \mu \mathrm{g} / \mathrm{ml}$ significantly had a low cytotoxicity, F-AFE at the same concentration suppressed the release of $\beta$-hexosaminidase, TNF- $\alpha$ and $\mathrm{PGE}_{2}$. These results suggest that $\mathrm{F}$-AFE at only $500 \mu \mathrm{g} / \mathrm{ml}$ may inhibit the growth of mast cells or induces the apoptosis of mast cells. To conclude, F-AFE (at $500 \mu \mathrm{g} / \mathrm{ml}$ ) may not only directly inhibit the allergic response in IgE-activated mast cells, but may also induce a decrease in the number of mast cells. Such effects of F-AFE may contribute to the enhancement of its anti-allergic effects.

As regards the intracellular mechanisms responsible for the anti-allergic effects of F-AFE, one possible mechanism is associated with a direct suppression of a signaling cascade of FceRI receptor, a high affinity IgE receptor (31). The degranulation in IgE-activated mast cells correlates with the activation of the FceRI receptor, located on the extracellular plasma membrane of mast cells or basophils (31). When IgE-activated mast cells liberates granules to the extracellular space, a number of pro-inflammatory mediators, such as TNF- $\alpha$, histamine, prostaglandins and leukotrienes are released from the cells (15), and these mediators then induce acute and chronic inflammation. Therefore, the key function of an anti-allergic action is to regulate the activation of the FceRI cascade. In this regard, Fyn, Lyn and Syk are known as rate-limiting factors of the FceRI signaling cascade $(32,33)$. Their activation induces the elevation of intracellular $\mathrm{Ca}^{2+}$ levels and the activation of the mitogenactivated protein kinase family, such as ERK, JNK and p38 (32). Therefore, Fyn, Lyn and Syk are the key signaling proteins of FceRI cascade in the early phase. In the present study, the inhibitory effects of F-AFE on the phosphorylation of Lyn, Fyn or Syk may support the notion that one of the anti-allergic targets for F-AFE may be Lyn, Fyn or Syk. In support of this hypothesis, in our study, F-AFE significantly inhibited the phosphorylation of ERK, JNK, p38 and Akt. Additionally, F-AFE also reduced the phosphorylation of PLC $\gamma 1 / 2$ and PKC $\delta$ in a concentration-dependent manner. It is known that the degranulation of IgE-activated mast cells is involved in the activation of the Syk/PLC $\gamma /$ PKC $\delta$ pathway in the FceRI cascade (20).

Separately, as previously demonsrated, the production of eicosanoids, including prostaglandins and leukotrienes in IgE-activated mast cells is intimately related with the activation of the FceRI cascade $(20,22)$. Eicosanoids, such as $\mathrm{PGE}_{2}, \mathrm{PGD}_{2}, \mathrm{LTB}_{4}$ and $\mathrm{LTC}_{4}$ are able to induce or aggravate acute and chronic inflammation in allergic diseases, such as asthma and allergic rhinitis (34). Therefore, the formation of eicosanoids in IgE-activated mast cells is another target of the anti-allergic actions of F-AFE. In this study, F-AFE not only reduced the levels of $\mathrm{PGE}_{2}$, which is involved in asthma development and inflammation related with interleukin (IL)-4 and IL-5 (23), but also suppressed the phosphorylation of $\mathrm{CPLA}_{2}$ in IgE-activated RBL-2H3 cells. This suggests that F-AFE inhibits the biosynthesis of prostaglandins through the inhibition of $\mathrm{CPLA}_{2}$, a rate-limiting enzyme of the arachidonate cascade. Besides, the inhibitory effects of F-AFE on the activation of $\mathrm{CPLA}_{2}$ may support the reduction of leukotriene biosynthesis in IgE-activated mast cells. Such effects of F-AFE may contribute to the improvement of its anti-allergic effects on allergic diseases.

In conclusion, this study demonstrates that AFE or F-AFE exert anti-allergic effects, and that the fermentation process enhances the anti-allergic effects of AFE by converting arctiin, a lignan glycoside, to arctigenin, an aglycone. These findings reveal a novel feature of F-AFE in allergic reactions. The mechanisms responsible for its anti-allergic effects may involve various targets, such as Lyn, Fyn, Syk and cPLA ${ }_{2}$, as well as pro-inflammatory mediators. Such effects may be due to several compounds in the Arctium lappa fruit, and may aid in the development of a functional food or a preventive agent for allergic diseases.

\section{Acknowledgements}

This study was supported by Grant K15280 from the Korea Institute of Oriental Medicine, Ministry of Education, Science and Technology (MEST), Republic of Korea.

\section{References}

1. Liu J, Cai YZ, Wong RN, Lee CK, Tang SC, Sze SC, Tong Y and Zhang Y: Comparative analysis of caffeoylquinic acids and lignans in roots and seeds among various burdock (Arctium lappa) genotypes with high antioxidant activity. J Agric Food Chem 60: 4067-4075, 2012.

2. MatsumotoT,Hosono-Nishiyama Kand YamadaH: Antiproliferative and apoptotic effects of butyrolactone lignans from Arctium lappa on leukemic cells. Planta Med 72: 276-278, 2006. 
3. Knott A, Reuschlein K, Mielke H, Wensorra U, Mummert C, Koop U, Kausch M, Kolbe L, Peters N, Stäb F, et al: Natural Arctium lappa fruit extract improves the clinical signs of aging skin. J Cosmet Dermatol 7: 281-289, 2008

4. Xu Z, Wang X, Zhou M, Ma L, Deng Y, Zhang H, Zhao A, Zhang Y and Jia W: The antidiabetic activity of total lignan from Fructus Arctii against alloxan-induced diabetes in mice and rats. Phytother Res 22: 97-101, 2008.

5. Lee IA, Joh EH and Kim DH: Arctigenin isolated from the seeds of Arctium lappa ameliorates memory deficits in mice. Planta Med 77: 1525-1527, 2011.

6. Yang YN, Huang XY, Feng ZM, Jiang JS and Zhang PC: Hepatoprotective activity of twelve novel 7'-hydroxy lignan glucosides from Arctii Fructus. J Agric Food Chem 62: 9095-9102, 2014.

7. Wu X, Yang Y, Dou Y, Ye J, Bian D, Wei Z, Tong B, Kong L, Xia Y and Dai Y: Arctigenin but not arctiin acts as the major effective constituent of Arctium lappa L. fruit for attenuating colonic inflammatory response induced by dextran sulfate sodium in mice. Int Immunopharmacol 23: 505-515, 2014.

8. BoldizsárI,FüzfaiZ,TóthF, SedlákE,Borsodi Land Molnár-Perl I: Mass fragmentation study of the trimethylsilyl derivatives of arctiin, matairesinoside, arctigenin, phylligenin, matairesinol, pinoresinol and methylarctigenin: Their gas and liquid chromatographic analysis in plant extracts. J Chromatogr A 1217: 1674-1682, 2010.

9. Oh YC, Cho WK, Oh JH, Im GY, Jeong YH, Yang MC and Ma JY: Fermentation by Lactobacillus enhances anti-inflammatory effect of Oyaksungisan on LPS-stimulated RAW 264.7 mouse macrophage cells. BMC Complement Altern Med 12: 17, 2012.

10. Kim A, Im M, Hwang YH, Yang HJ and Ma JY: Jaeumganghwa-tang induces apoptosis via the mitochondrial pathway and Lactobacillus fermentation enhances its anticancer activity in HT1080 human fibrosarcoma cells. PLoS One 10: e0127898, 2015

11. Kim JH, Park TS, Yang SH, Suh JW and Shim SM: Microbial bioconversion and processing methods enhance the phenolic acid and flavonoids and the radical scavenging capacity of Smilax china L. leaf. J Sci Food Agric: Mar 5, 2015 (Epub ahead of print). doi: 10.1002/jsfa.7160.

12. Sheih IC, Fang TJ, Wu TK, Chang CH and Chen RY: Purification and properties of a novel phenolic antioxidant from Radix astragali fermented by Aspergillus oryzae M29. J Agric Food Chem 59: 6520-6525, 2011.

13. Uzzaman A and Cho SH: Chapter 28: Classification of hypersensitivity reactions. Allergy Asthma Proc 33 (Suppl 1): S96-S99, 2012.

14. Theoharides TC and Kalogeromitros D: The critical role of mast cells in allergy and inflammation. Ann NY Acad Sci 1088: 78-99, 2006.

15. Gilfillan AM and Tkaczyk C: Integrated signalling pathways for mast-cell activation. Nat Rev Immunol 6: 218-230, 2006.

16. Chung TH, Kang TJ, Cho WK, Im GY, Lee GS, Yang MC Cho CW and Ma JY: Effectiveness of the novel herbal medicine, KIOM-MA, and its bioconversion product, KIOM-MA128, on the treatment of atopic dermatitis. Evid Based Complement Alternat Med 2012: 762918, 2012.

17. Wang W, Pan Q, Han XY, Wang J, Tan RQ, He F, Dou DQ and Kang TG: Simultaneous determination of arctiin and its metabolites in rat urine and feces by HPLC. Fitoterapia 86: 6-12, 2013

18. Morita Y and Siraganian RP: Inhibition of IgE-mediated histamine release from rat basophilic leukemia cells and rat mast cells by inhibitors of transmethylation. J Immunol 127 : $1339-1344,1981$
19. Ishiyama M, Tominaga $\mathrm{H}$, Shiga M, Sasamoto K, Ohkura $\mathrm{Y}$ and Ueno K: A combined assay of cell viability and in vitro cytotoxicity with a highly water-soluble tetrazolium salt, neutral red and crystal violet. Biol Pharm Bull 19: 1518-1520, 1996.

20. Yoo JM, Kim NY, Seo JM, Kim SJ, Lee SY, Kim SK, Kim HD Lee SW and Kim MR: Inhibitory effects of mulberry fruit extract in combination with naringinase on the allergic response in IgE-activated RBL-2H3 cells. Int J Mol Med 33: 469-477, 2014.

21. Russo $\mathrm{C}$ and Polosa R: TNF-alpha as a promising therapeutic target in chronic asthma: A lesson from rheumatoid arthritis. Clin Sci (Lond) 109: 135-142, 2005.

22. Yoo JM, Sok DE and Kim MR: Anti-allergic action of aged black garlic extract in RBL-2H3 cells and passive cutaneous anaphylaxis reaction in mice. J Med Food 17: 92-102, 2014.

23. van der Pouw Kraan TC, Boeije LC, Smeenk RJ, Wijdenes J and Aarden LA: Prostaglandin- $\mathrm{E}_{2}$ is a potent inhibitor of human interleukin 12 production. J Exp Med 181: 775-779, 1995.

24. Ford-Hutchinson AW, Bray MA, Doig MV, Shipley ME and Smith MJ: Leukotriene B, a potent chemokinetic and aggregating substance released from polymorphonuclear leukocytes. Nature 286: 264-265, 1980.

25. Arima $M$ and Fukuda T: Prostaglandin $D_{2}$ and $T(H) 2$ inflammation in the pathogenesis of bronchial asthma. Korean J Intern Med 26: 8-18, 2011.

26. Nettis E, D'Erasmo M, Di Leo E, Calogiuri G, Montinaro V, Ferrannini A and Vacca A: The employment of leukotriene antagonists in cutaneous diseases belonging to allergological field. Mediators Inflamm 2010: 628171, 2010.

27. Kawakami Y, Kitaura J, Satterthwaite AB, Kato RM, Asai K, Hartman SE, Maeda-Yamamoto M, Lowell CA, Rawlings DJ, Witte ON, et al: Redundant and opposing functions of two tyrosine kinases, Btk and Lyn, in mast cell activation. J Immunol 165: 1210-1219, 2000

28. Choi SY, Hwang JH, Park SY, Jin YJ, Ko HC, Moon SW and Kim SJ: Fermented guava leaf extract inhibits LPS-induced COX-2 and iNOS expression in mouse macrophage cells by inhibition of transcription factor NF-kappaB. Phytother Res 22: 1030-1034, 2008

29. Liu H, Zhang Y, Sun Y, Wang X, Zhai Y, Sun Y, Sun S, Yu A, Zhang $\mathrm{H}$ and Wang Y: Determination of the major constituents in fruit of Arctium lappa L. by matrix solid-phase dispersion extraction coupled with HPLC separation and fluorescence detection. J Chromatogr B Analyt Technol Biomed Life Sci 878: 2707-2711, 2010

30. Zhao F, Wang L and Liu K: In vitro anti-inflammatory effects of arctigenin, a lignan from Arctium lappa L., through inhibition on iNOS pathway. J Ethnopharmacol 122: 457-462, 2009.

31. Theoharides TC, Alysandratos KD, Angelidou A, Delivanis DA, Sismanopoulos N, Zhang B, Asadi S, Vasiadi M, Weng Z, Miniati A, et al: Mast cells and inflammation. Biochim Biophys Acta 1822: 21-33, 2012.

32. Roth K, Chen WM and Lin TJ: Positive and negative regulatory mechanisms in high-affinity IgE receptor-mediated mast cell activation. Arch Immunol Ther Exp (Warsz) 56: 385-399, 2008.

33. Gomez G, Gonzalez-Espinosa C, Odom S, Baez G, Cid ME, Ryan JJ and Rivera J: Impaired FcepsilonRI-dependent gene expression and defective eicosanoid and cytokine production as a consequence of Fyn deficiency in mast cells. J Immunol 175: 7602-7610, 2005.

34. Fanning LB and Boyce JA: Lipid mediators and allergic diseases. Ann Allergy Asthma Immunol 111: 155-162, 2013. 